\title{
Effect of oak acorn (Quercus ilex) intake during suckling and fattening of Barbarine lambs on growth, meat quality and fatty acid profile
}

\author{
I. Mekki', S. Smeti', H. Hajji', ${ }^{12}$, Y. Yagoubi', M. Mahouachi' ${ }^{3}$ and N. Atti ${ }^{1,4}$ \\ 1 University of Carthage, Laboratory of Animal and Forage Production, \\ National Institute of Agricultural Research of Tunisia (INRAT), 2049 Ariana, Tunisia \\ ${ }^{2}$ University of Gabes, Livestock and Wildlife Laboratory, Arid Regions Institute (IRA), 4119 Médenine, Tunisia \\ ${ }^{3}$ University of Jendouba, ESAK, 7100 Le Kef, Tunisia
}

KEY WORDS: oak acorns, barley, lambs, performance traits, meat quality, fatty acids

Received: 2 December 2017

Revised: 4 November 2018

Accepted: 23 February 2019

${ }^{4}$ Corresponding author:

e-mail: naziha.belhaj@iresa.agrinet.tn

\begin{abstract}
The objective of the present study was to evaluate the effects of oak acorn (Quercus ilex) intake before and after weaning on lamb growth, meat properties and fatty acid (FA) composition. In total 32 Barbarine male lambs were divided into 4 groups, 8 lambs in each. Before weaning, 16 lambs were reared with their dams on range pasture; each mother-lamb pair received $400 \mathrm{~g}$ of barley concentrate. The other 16 were reared with their dams on forest pasture; each mother-lamb pair received $300 \mathrm{~g}$ of oak acorn concentrate. During the fattening period, lambs were reared in feedlot on one of the 4 dietary treatments - based on concentrate of barley alone or barley plus acorn. Both BarBar and BarAco groups received barley while suckling, and then barley and acorn, respectively, for the fattening period. AcoBar and AcoAco groups received acorn while suckling and then barley and acorn, respectively, for the fattening period. Acorn intake affected neither growth rate nor the physicochemical traits of meat (except $\mathrm{pH}$ measured $1 \mathrm{~h}$ post mortem). The sum of saturated FA was similar in all groups, whereas $\mathrm{C} 18: 0$ was higher in AcoAco and BarAco animals $(P<0.01)$ than in AcoBar and BarBar (about 25 and $22 \%$, respectively). The total monounsaturated FA and polyunsaturated FA did not differ among the groups, except C18:3n-3 which was higher in the AcoAco and AcoBar $(P<0.01)$ than in BarBar group $(0.37$ and $0.18 \%$, respectively). The AcoAco group had the highest meat sensory parameters (tenderness, juiciness and general acceptance). So, it may be concluded that ground oak acorn can be used up to $40 \%$ in lamb diets without any unfavourable effects on growth performance or meat characteristics.
\end{abstract}

\section{Introduction}

Sheep are often grazed on natural resources, rangelands and stubbles or in feedlots with varying amounts of concentrate. All of this result in variable product quality. However, ruminant meat produced on grassland, natural pasture or forest is thought to be the best for consumers ( $\AA$ dnøy et al., 2005; Smeti et al., 2014; Mekki et al., 2016). Therefore, some local animal feedstuffs could be used to improve organic agriculture systems according to the sustainability principle (House of Lords Select Committee on the European Communities, 1999) giving sheep owners the possibility to diversify their production 
and produce high quality lamb meat. Oak acorn a cheap woody plant readily available in many countries is among such feedstuffs. It is the fruit of Quercus ilex (green oak), one of the most common forest trees in the Mediterranean area.

The dietetic quality of meat is mainly determined by its physicochemical characteristics, prominently judged by fatty acid (FA) composition: a high content of saturated fatty acid (SFA) is considered harmful for human health whereas that of polyunsaturated (PUFA) beneficial (Simopoulos, 2008). Nutritional treatments are used to increase animal growth and manipulate the FA content improving the nutritional value of meat (Atti and Mahouachi, 2009; Ponnampalam et al., 2016). Oak acorn, due to its high content of $\mathrm{C} 18: 1$, has an interesting FA profile (Cantos et al., 2003; Akcan et al., 2017) and so is largely used in pig production (Jurado et al., 2007; Pérez-Palacios, 2010). However, available data linking its effects on small ruminant growth and meat quality is very limited (Keddam et al., 2010).

Due to the lack of knowledge of the effects of ground oak acorn on lamb performance and meat quality, the aim of the present study was to evaluate the effect of oak intake before and after weaning on lamb growth, meat properties and FA composition. Our hypothesis was twofold: (i) does acorn consumed in a forest pasture by suckling lambs with their dams affect their growth and qualitative characteristics when fattened with acorn or conventional concentrate; and (ii) could lambs on a conventional regimen attain specific characteristics when fattened with acorn?

\section{Material and methods}

\section{Animal management and experimental feeds}

The fattening trial was carried out at the National Institute of Agricultural Research of Tunisia (INRAT) on 32 Barbarine male lambs weaned at 4 months old at $17.5 \pm 1.5 \mathrm{~kg}$ body weight (BW). Before weaning, lambs were reared in two different sites: 16 of them were reared on conventional pasture on an experimental farm where each mother-lamb pair received $400 \mathrm{~g}$ of barley grain concentrate and the other 16 lambs were reared on forest pasture in a mountainous region; each mother-lamb pair received $300 \mathrm{~g}$ of oak acorn concentrate. Acorns were limited to about $200 \mathrm{~g}$ for mothers and $100 \mathrm{~g}$ for lambs as typically applied by the breeders in this region.

During the fattening period, only the lambs were assigned to 4 groups of 8 animals each. The groups were divided according to either concentrate type - barley or acorn, or feeding period - suckling or fattening. Measurements were taken during respective period of feeding. The BarBar group received barley concentrate in both the suckling and fattening periods; the BarAco group received barley concentrate in the suckling period and acorn in the fattening period. The AcoBar group received acorn in the suckling period and barley concentrate in the fattening phase whereas the AcoAco group received acorn concentrate during both periods. All lambs were housed in individual boxes; they had free access to water and received daily $400 \mathrm{~g}$ of oat hay and $700 \mathrm{~g}$ of concentrate per animal in two equal meals at 9:00 and 14:00. Lambs were weighed on the same day every week just before the feed distribution.

In the barley concentrate the main source of energy was barley whereas the acorn concentrate replaced $40 \%$ of the barley with acorn. The concentrate formulas and nutritional values of the feeds are given in Table 1. Both types of concentrate were similar in terms of energy and protein content and met the requirements of growing lambs (Hassoun and Bocquier, 2010). For the test concentrate, after harvesting green oak acorns (the fruit of Quercus ilex), the kernel (all of the dicotyledons) was immediately ground and dried in fresh open air. The acorn powder was then incorporated into the acorn concentrate formula.

Table 1. Constituents, chemical composition and fatty acid (FA) profile of experimental feeds offered during fattening period

\begin{tabular}{|c|c|c|c|c|c|}
\hline \multirow{2}{*}{ Indices } & \multirow{2}{*}{ Oat hay } & \multirow{2}{*}{ Barley } & \multirow{2}{*}{ Acorn } & \multicolumn{2}{|c|}{ Concentrate } \\
\hline & & & & barley a & acorn \\
\hline \multicolumn{6}{|l|}{ Constituents, \% } \\
\hline barley & - & - & - & 76 & 38 \\
\hline soybean & - & - & - & 12 & 12 \\
\hline wheat bran & - & - & - & 9 & 9 \\
\hline acorn & - & - & - & - & 38 \\
\hline $\begin{array}{l}\text { mineral-vitamin- } \\
\text { supplement }\end{array}$ & - & - & - & 3 & 3 \\
\hline \multicolumn{6}{|c|}{ Chemical composition, \% dry matter (DM) } \\
\hline $\mathrm{DM}, \%$ & 91 & 96 & 78 & 90 & 91 \\
\hline crude protein & 6.3 & 8.2 & 7.3 & 13.1 & 12.3 \\
\hline crude fibre & 65.9 & 28.0 & 38.8 & 26.0 & 25.9 \\
\hline total phenolic content & - & - & 4.3 & - & 3.2 \\
\hline energy, kcal/kg & 670 & 1600 & 1790 & 14701 & 1505 \\
\hline \multicolumn{6}{|c|}{ FA composition, $\%$ of total FA } \\
\hline C16:0 & 24.7 & 21.1 & 17.2 & 25.1 & 24.7 \\
\hline C18:0 & 4.20 & 1.72 & 1.40 & 4.55 & 3.97 \\
\hline C18:1 & 9.50 & 51.9 & 56.2 & 31.8 & 32.9 \\
\hline C18:2 & 16.0 & 18.2 & 21.2 & 28.1 & 31.2 \\
\hline C18:3 & 11.1 & 0.23 & 1.50 & 1.12 & 1.43 \\
\hline saturated FA & 39.3 & 21.5 & 20.1 & 31.9 & 30.1 \\
\hline monounsaturated FA & 9.54 & 52.4 & 56.9 & 32.6 & 34.1 \\
\hline polyunsaturated FA & 27.1 & 18.5 & 22.8 & 29.0 & 32.6 \\
\hline
\end{tabular}




\section{Slaughter procedure and meat sampling}

At the end of the trial, all lambs were slaughtered. The carcasses were refrigerated for $24 \mathrm{~h}$ at $4{ }^{\circ} \mathrm{C}$; after removing the tail, the carcasses were split longitudinally into two halves. The longissimus dorsi (LD) muscle was removed from the left half. The subcutaneous fat colour parameters were measured on raw muscle. Then, the subcutaneous fat was removed and the muscle was divided into 5 parts, two of which were immediately used for $\mathrm{pH}$, muscle colour parameters and water cooking loss determinations. One sample was dried by lyophilisation, ground (sieved through a 1-mm screen) and stored for subsequent chemical analysis (ash, protein and fat). The last two samples were frozen at $-20^{\circ} \mathrm{C}$ for later evaluation of sensory quality and fatty acid content.

\section{Physical and chemical analyses of meat}

The $\mathrm{pH}$ was measured $1 \mathrm{~h}$ and $24 \mathrm{~h}$ post mortem with a penetrating electrode connected to a portable pH-meter (Orion 9106, Orion Research Inc., Boston, MA, USA) after calibration with two buffers (7.01 and 4.01). For subcutaneous fat and meat colour parameters: $\mathrm{L}^{*}$ (lightness), a* (redness) and $\mathrm{b}^{*}$ (yellowness) measurements, a Minolta CM-2006 d spectrophotometer (Konica Minolta Holdings, Inc, Osaka, Japan) was used. To determine water cooking loss (WCL), meat samples of LD muscle were weighed (initial weight, $\mathrm{W}_{\mathrm{i}}$ ) and held in plastic bags and then immersed in a water bath at $75{ }^{\circ} \mathrm{C}$ and heated for 30 min until the internal temperature reached $75^{\circ} \mathrm{C}$, which was monitored with a thermocouple. Then, the bags were cooled under running tap water for $30 \mathrm{~min}$ and blotted dry with paper towels. The cooked meat was weighed again (final weight, $\mathrm{W}_{\mathrm{f}}$ ) and $\mathrm{WCL}$ $(\mathrm{g} / \mathrm{kg})$ was calculated as: $1000 \times\left(\mathrm{W}_{\mathrm{i}}-\mathrm{W}_{\mathrm{f}}\right) / \mathrm{W}_{\mathrm{i}}$.

Samples of LD muscle were dried by lyophilisation and ground. The ash content was determined by aching at $600^{\circ} \mathrm{C}$ for $8 \mathrm{~h}$. Nitrogen was determined by the Kjeldahl method using Büchi Digestion Automat K-438 and Büchi Distillation Unit B-324 (Büchi Laboratory Equipment, Flawil, Switzerland). The protein content was calculated as $\mathrm{N} \times 6.25$. Intramuscular fat (IMF) was extracted using an automated Soxhlet apparatus (Büchi Labortechnik AG, Flawil, Switzerland) with hexane as a solvent (AOAC, 1991).

\section{Fatty acid analysis}

Intramuscular fat was extracted according to the Bligh and Dyer (1959) method. Methyl esters were separated and quantified by capillary gas chromatography. Fatty acid methyl esters (FAMEs) were prepared by base-catalysed methanolysis of the glycerides with $\mathrm{KOH}$ according to the BS EN ISO 5509:2001. A Hewlett-Packard chromatograph (HP-5890) equipped with a split/splitless injector and a flame ionization detector (Thermo Finnigan, Les Ulis, France) was used. The FAMEs samples were separated on a fused silica capillary column $(100 \mathrm{~m} \times 0.25 \mathrm{~mm} ; 0.20 \mathrm{~mm}$ thickness; CP-Sil 88, Chrompack and Middelburg, Bruker Nederland B.V., Leiderdorp, The Netherlands). The injector temperature was maintained at $250^{\circ} \mathrm{C}$ and the detector temperature at $255^{\circ} \mathrm{C}$. The carrier gas was hydrogen. FA identification was based on retention times compared with those of fatty acids methyl standards; their values were expressed in $\mathrm{g} / 100 \mathrm{~g}$ total FA.

The groups of FA were calculated according to saturation level and unsaturation position. They concerned namely the sum of SFA, monounsaturated FA (MUFA) and PUFA, total n-6 and n-3 PUFA, total isomers of conjugated linoleic acid (CLA) and the desirable FA (DFA) = MUFA + PUFA + C18:0. Moreover, the PUFA:SFA and n6:n3 ratios were calculated. According to Ulbricht and Southgate (1991), atherogenic (AI) and thrombogenic (TI) indexes were calculated as:

$$
\begin{gathered}
\mathrm{AI}=(\mathrm{C} 12: 0+4 \times \mathrm{C} 14: 0+\mathrm{C} 16: 0) /(\Sigma \mathrm{n}-6+\Sigma \mathrm{n}-3+ \\
\quad \Sigma \text { MUFA }) \\
\mathrm{TI}=(\mathrm{C} 14: 0+\mathrm{C} 16: 0+\mathrm{C} 18: 0) /(0.5 \times \Sigma \mathrm{MUFA}+ \\
0.5 \times \Sigma \mathrm{n}-6+3 \times \Sigma \mathrm{n}-3+\Sigma \mathrm{n}-3 / \Sigma \mathrm{n}-6) .
\end{gathered}
$$

\section{Sensory analysis}

All samples were packed and frozen at $21^{\circ} \mathrm{C}$ until evaluation. Before the sensory session, samples were thawed at $4{ }^{\circ} \mathrm{C}$, wrapped in aluminium foil, and then placed in a preheated oven to $180^{\circ} \mathrm{C}$ until the core temperature reached $71^{\circ} \mathrm{C}$ (AMSA, 2015). Immediately after cooking, muscle was divided into $1 \times 1 \mathrm{~cm}$ cubed samples and placed on white plastic trays covered with aluminium foil. The trays were individually marked with three random digits and presented to a trained 12-member sensory panel. Meat samples were evaluated for tenderness (scale of $1-10 ; 1=$ extremely tough, $10=$ extremely tender), juiciness (scale $1-10 ; 1=$ extremely dry, $10=$ extremely juicy), flavour (scale $1-10 ; 1=$ very poor, $10=$ very good) and overall acceptability (scale $1-10$; $1=$ not acceptable, $10=$ extremely acceptable). Bread and water were provided for the panellists to fresh their mouths after every two samples.

\section{Statistical analysis}

A one-way ANOVA was used to test the effect of dietary treatments on lamb growth, and meat characteristics, sensory evaluation and FA profile using a GLM (General Linear Model) in SAS software 
(SAS Institute Inc., Cary, NC, USA). The analyses were performed with diet as a fixed effect and animal as a random effect. Differences between diets were evaluated by Tukey's test and significance was declared at $P<0.05$ and tendency was considered if $P<0.10$. The following contrasts were used to compare the effects of the different diets:

- $\mathrm{C}_{1}$ : acorn vs barely diet during the fattening period [BarAco + AcoAco vs BarBar + AcoBar];

- $\mathrm{C}_{2}$ :acorn vs barely diet during the suckling period $[$ BarAco + BarBar vs AcoAco + AcoBar];

- $\mathrm{C}_{3}$ : acorn vs barely diet regardless of the period [BarAco + AcoAco + AcoBar vs BarBar $]$.

\section{Results}

\section{Diet intake and growth performances}

Among groups a similar intake of hay and concentrate $(P>0.05)$ resulting in average values of 310 and $620 \mathrm{~g} / \mathrm{d}$, respectively, was noted. The growth rate was not affected by the dietary treatment averaging $145 \mathrm{~g} / \mathrm{d}$ for all groups. The mean final body weight was $28 \mathrm{~kg}$ without significant differences between the groups (Table 2).

Table 2. Growth performances

\begin{tabular}{|c|c|c|c|c|c|c|}
\hline \multirow[b]{2}{*}{ Indices } & Groups $^{1}$ & \multicolumn{5}{|c|}{ Statistics ${ }^{2}$} \\
\hline & $\begin{array}{llll}\text { Aco- } & \text { Aco- } & \text { Bar- } & \text { Bar- } \\
\text { Aco Bar Aco } & \text { Bar }\end{array}$ & $\begin{array}{l}P- \\
\text { value }\end{array}$ & SEM & $\mathrm{C}_{1}$ & $\mathrm{C}_{2}$ & $\mathrm{C}_{3}$ \\
\hline IBW, kg & $\begin{array}{llll}17.3 & 17.5 & 16.8 & 16.9\end{array}$ & 0.47 & 1.47 & 0.32 & 0.91 & 0.66 \\
\hline SBW, $\mathrm{kg}$ & $\begin{array}{llll}28.4 & 28.3 & 28.7 & 28.0\end{array}$ & 0.79 & 1.79 & 0.88 & 0.26 & 0.35 \\
\hline $\mathrm{BG}, \mathrm{kg}$ & $\begin{array}{llll}11.1 & 10.8 & 11.9 & 11.1\end{array}$ & 0.54 & 1.42 & 0.83 & 0.72 & 0.45 \\
\hline$A D G, g / d$ & $\begin{array}{llll}147 & 143 & 146 & 145\end{array}$ & 0.67 & 12.7 & 0.78 & 0.23 & 0.21 \\
\hline
\end{tabular}

${ }^{1}$ Groups: AcoAco - lambs receiving acorn concentrate during the suckling and fattening periods, AcoBar - lambs receiving acorn in the suckling period and barley concentrate in the fattening period, BarAco lambs receiving barley concentrate in the suckling period and acorn in the fattening period, BarBar - lambs receiving barley concentrate in both suckling and fattening periods; ${ }^{2}$ Statistics: SEM - standard error of means, $C_{1}$ - contrast : [AcoAco + BarAco vs AcoBar + BarBar $]$, $\mathrm{C}_{2}$ - contrast ${ }_{2}:[\mathrm{AcoAco}+\mathrm{AcoBar}$ vs BarAco + BarBar $]$, $\mathrm{C}_{3}$ - contrast ${ }_{3}[\mathrm{AcOAco}+\mathrm{BarAco}+\mathrm{AcoBar}$ vs BarBar]; IBW initial body weight; SBW - slaughter body weight; BG - body gain; $A D G$ - average daily gain

\section{Meat physical and chemical characteristics}

The initial $\mathrm{pH}\left(\mathrm{pH}_{\mathrm{lh}}\right)$ and the difference between initial and ultimate $\mathrm{pH}\left(\mathrm{pH}_{1 \mathrm{~h}}-\mathrm{pH}_{24 \mathrm{~h}}\right)$ were the highest in BarAco (but did not differ from AcoAco) and the lowest in AcoBar group (but did not differ from BarBar); the values for AcoAco and BarBar did not differ among each other (Table 3). However, the contrast $\mathrm{C}_{2}$ was significant $(P<0.01$ for both param-
Table 3. Meat physical characteristics and chemical composition

\begin{tabular}{|c|c|c|c|c|c|c|c|c|c|}
\hline \multirow[b]{2}{*}{ Indices } & \multicolumn{4}{|c|}{ Groups $^{1}$} & \multicolumn{5}{|c|}{ Statistics ${ }^{2}$} \\
\hline & $\begin{array}{l}\text { Aco- } \\
\text { Aco }\end{array}$ & $\begin{array}{l}\text { Aco- } \\
\text { Bar }\end{array}$ & $\begin{array}{l}\text { Bar- } \\
\text { Aco }\end{array}$ & $\begin{array}{l}\text { Bar- } \\
\text { Bar }\end{array}$ & $\begin{array}{l}P- \\
\text { value }\end{array}$ & SEM & $\mathrm{C}_{1}$ & $\mathrm{C}_{2}$ & $\mathrm{C}_{3}$ \\
\hline $\mathrm{pH}_{1 \mathrm{~h}}$ & $6.11^{\mathrm{ab}}$ & $6.01^{\circ}$ & ${ }^{c} 6.31^{\mathrm{a}}$ & $6.08^{b c}$ & 0.02 & 0.25 & 0.07 & 0.001 & 10.25 \\
\hline $\mathrm{pH}_{24 h}$ & 5.60 & 5.54 & 5.62 & 5.53 & 0.66 & 0.13 & 0.77 & 0.255 & 50.78 \\
\hline $\mathrm{pH}_{1 \mathrm{~h}}-\mathrm{pH}_{24 \mathrm{~h}}$ & $0.51^{b c}$ & ${ }^{c} 0.47^{\circ}$ & ${ }^{c} 0.69^{a}$ & $0.55^{\mathrm{ab}}$ & 0.02 & 0.20 & 0.03 & 0.001 & 10.20 \\
\hline $\begin{array}{l}\text { Water } \\
\text { cooking } \\
\text { loss, } \%\end{array}$ & 23.5 & 25.4 & 21.3 & 24.1 & 0.28 & 6.31 & 0.12 & 0.20 & 0.96 \\
\hline $\begin{array}{l}\text { Dry matter } \\
\text { (DM), \% }\end{array}$ & 25.1 & 24.2 & 25.1 & 24.8 & 0.53 & 1.20 & 0.20 & 0.54 & 0.95 \\
\hline $\begin{array}{l}\text { Protein, } \\
\% \text { DM }\end{array}$ & 72.5 & 73.0 & 72.0 & 74.5 & 0.17 & 2.20 & 0.08 & 0.57 & 0.06 \\
\hline
\end{tabular}

$\begin{array}{lllllllll}\text { Ash, \% DM } 4.2 & 4.7 & 4.0 & 4.0 & 0.34 & 2.23 & 0.23 & 0.37 & 0.07\end{array}$ $\begin{array}{lllllllll}\text { Fat, \% DM } 23.1 & 22.9 & 23.1 & 21.3 & 0.23 & 0.72 & 0.11 & 0.28 & 0.41\end{array}$ Muscle colour

$\begin{array}{lccccccccc}\mathrm{L}^{*} & 41.7 & 42.4 & 41.9 & 43.6 & 0.11 & 0.52 & 0.96 & 0.10 & 0.17 \\ \mathrm{a}^{*} & 16.1 & 16.1 & 15.8 & 16.4 & 0.90 & 1.78 & 0.57 & 0.88 & 0.51 \\ \mathrm{~b}^{*} & 6.12 & 7.84 & 6.33 & 6.85 & 0.52 & 1.78 & 0.40 & 0.76 & 0.67\end{array}$

Fat colour

$\begin{array}{llllllllll}L^{*} & 68.9 & 66.5 & 70.8 & 68.7 & 0.17 & 3.58 & 0.09 & 0.12 & 0.99\end{array}$

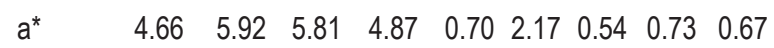
\begin{tabular}{llllllllll}
$b^{*}$ & 9.86 & 10.20 & 9.51 & 9.40 & 0.87 & 2.08 & 0.88 & 0.44 & 0.59 \\
\hline
\end{tabular}

1 and 2 - see Table 2; ab - means within a row with different superscripts are significantly different at $P<0.05$

eters) indicating higher values for lambs fed acorn in the suckling phase. The ultimate $\mathrm{pH}\left(\mathrm{pH}_{24 \mathrm{~h}}\right)$ and the WCL were similar among all groups $(P>0.05)$. The values of colour parameters: $\mathrm{L}^{*}, \mathrm{a}^{*}$ and $\mathrm{b}^{*}$, averaged $42.4,16.1$ and 6.8 for LD muscle, respectively, and $68.7,5.3$ and 9.7 for subcutaneous fat, respectively, without any difference between the groups (Table 3). The dietary treatment did not influence the meat chemical composition (Table 3).

\section{Meat fatty acid profile}

The individual FA contents are reported in Table 4. The palmitic (C16:0), stearic (C18:0) and oleic (C18:1) acids had the highest proportions of FA for all groups. Among SFA, C14:0 was higher in the groups fed acorn in the suckling phase (AcoAco and AcoBar) $\left(P<0.01\right.$ for contrast $\left.\mathrm{C}_{2}\right)$, however $\mathrm{C} 18: 0$ was higher in both groups fed acorn in the fattening phase (AcoAco and BarAco; 24.9 and $25.91 \%$, respectively) than in groups finished on barley (AcoBar and BarBar; 22.47 and 21.99\%, respectively) $\left(P<0.01\right.$ for contrast $\left.\mathrm{C}_{2}\right)$. The overall effect of dietary treatment on SFA was not significant, however the contrast $\mathrm{C}_{3}$ [BarAco, AcoBar, AcoAco vs BarBar] was significant indicating lower values in BarBar group. Neither total MUFA nor C18:1n-9c was affected by the dietary treatment. 
Table 4. Fatty acid (FA) composition (\% of total FA, index and ratios) in longissimus dorsi muscle of lambs

\begin{tabular}{|c|c|c|c|c|c|c|c|c|c|}
\hline \multirow[b]{2}{*}{ Indices } & \multicolumn{4}{|c|}{ Groups $^{1}$} & \multicolumn{5}{|c|}{ Statistics $^{2}$} \\
\hline & $\begin{array}{l}\text { Aco- } \\
\text { Aco }\end{array}$ & $\begin{array}{l}\text { Aco- } \\
\text { Bar }\end{array}$ & $\begin{array}{l}\text { Bar- } \\
\text { Aco }\end{array}$ & $\begin{array}{l}\text { Bar- } \\
\text { Bar }\end{array}$ & $\begin{array}{l}\overline{P-} \\
\text { value }\end{array}$ & S & $C_{1}$ & $C_{2}$ & $\mathrm{C}_{3}$ \\
\hline 14:0 & $2.86^{a}$ & $2.29^{a}$ & ab $1.81^{b}$ & $2.02^{b}$ & 0.04 & 0.706 & 0.13 & 0.01 & 0.30 \\
\hline $14: 1 n-5$ & 0.07 & 0.14 & 0.07 & 0.08 & 0.19 & 0.060 & 0.14 & 0.19 & 0.5 \\
\hline C15:0 & $0.38^{b}$ & $0.63^{a}$ & a $\quad 0.44^{\mathrm{ab}}$ & ab $0.51^{\mathrm{ab}}$ & 0.10 & 0.198 & 0.03 & 0.62 & 0.76 \\
\hline 16:0 & 24.52 & 24.34 & 23.58 & 24.35 & 0.71 & 1.758 & 0.64 & 0.46 & 0.7 \\
\hline $6: 1 n-$ & 1.49 & 1.44 & 1.09 & 1.39 & 0.37 & 0.490 & 0.49 & 0.20 & 0.06 \\
\hline 17:0 & $1.75^{b}$ & $2.30^{\mathrm{a}}$ & a $1.81^{b}$ & $1.94^{\mathrm{ab}}$ & 0.05 & 0.397 & 0.02 & 0.29 & 0.9 \\
\hline $17: 1 n-7$ & $0.52^{b}$ & $0.80^{\mathrm{a}}$ & a $0.61^{b}$ & $0.83^{a}$ & 0.05 & 0.145 & 0.01 & 0.22 & 0.03 \\
\hline 18:0 & $24.9^{\mathrm{a}}$ & $22.47^{\mathrm{b}}$ & 25.91 & $21.99^{b}$ & 0.01 & 2.383 & 0.01 & 0.88 & 0.0 \\
\hline 8:1n-9 & 28.54 & 26.31 & 25.89 & 30.86 & 0.10 & 4.544 & 0.32 & 0.23 & 0.08 \\
\hline C18:1 & 31.51 & 29.60 & 28.28 & 33.16 & 0.22 & 4.753 & 0.35 & 0.98 & 0.1 \\
\hline 18:2 & 0.31 & 0.33 & 0.35 & 0.27 & 0.55 & 0.111 & 0.45 & 0.80 & 0.26 \\
\hline $8 \cdot 2 \mathrm{n}-6$ & 5.57 & 7.14 & 6.70 & 5.19 & 0.437 & 2.136 & 0.73 & 0.98 & 0.0 \\
\hline $18: 3 n$ & $0.37^{a}$ & $0.37^{a}$ & a $\quad 0.28^{a b}$ & $0.18^{b}$ & 0.01 & 0.098 & 0.23 & 0.01 & 0.02 \\
\hline LLA & 0.44 & 0.52 & 0.38 & 0.31 & 0.30 & 0.162 & 0.66 & 0.05 & 0.07 \\
\hline $20: 0$ & 0.16 & 0.15 & 0.19 & 0.14 & 0.42 & 0.066 & 0.18 & 0.72 & 0.2 \\
\hline 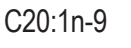 & $0.16^{b}$ & $0.26^{a}$ & a $0.16^{b}$ & $0.20^{\mathrm{ab}}$ & 0.11 & 0.090 & 0.45 & 0.03 & 0.8 \\
\hline C20:2n-6 & $0.56^{\mathrm{ab}}$ & $0.45^{b}$ & $0.80^{\mathrm{a}}$ & $0.46^{b}$ & 0.05 & 0.329 & 0.39 & 0.0 & 0. \\
\hline $20: 3 n-6$ & 0.25 & 0.29 & 0.32 & 0.30 & 0.81 & 0.159 & 0.89 & 0.45 & 0.8 \\
\hline$C 20: 5 n-3$ & 0.24 & 0.34 & 0.27 & 0.47 & 0.68 & 0.406 & 0.32 & 0.59 & 0.27 \\
\hline C21:5n-3 & 0.07 & 0.10 & 0.12 & 0.09 & 0.76 & 0.088 & 0.89 & 0.60 & 0.76 \\
\hline $2: 5 n-6$ & 0.18 & 0.21 & 0.31 & 0.23 & 0.66 & 0.117 & 0 & 0.0 & 0 \\
\hline $22: 5 n-3$ & $0.65^{\mathrm{a}}$ & $0.49^{b}$ & $0.66^{\mathrm{a}}$ & $0.52^{b}$ & 0.16 & 0.320 & 0.04 & 0. & \\
\hline$C 22: 6 n-3$ & 0.12 & 0.11 & 0.10 & 0.10 & 0.82 & 0.063 & 0.80 & 0.73 & 0.88 \\
\hline C24:0 & 0.16 & 0.11 & 0.20 & 0.15 & 0.23 & 0.081 & 0.11 & 0.18 & 0.88 \\
\hline SFA & 53.37 & 51.87 & 52.98 & 50.12 & 0.21 & 3.156 & 0.10 & 0.32 & 0.04 \\
\hline UFA & 32.24 & 30.71 & 29.23 & 34.28 & 0.17 & 4.740 & 0.24 & 0.96 & 0.08 \\
\hline DUFA & 9.92 & 12.73 & 13.11 & 10.43 & 0.42 & 4.353 & 0.82 & 0.52 & 0.5 \\
\hline$n-6$ FA & 8.35 & 10.71 & 11.31 & 8.78 & 0.36 & 3.712 & 0.74 & 0.43 & 0.52 \\
\hline $\mathrm{n}-3 \mathrm{FA}$ & 1.29 & 1.68 & 1.44 & 1.37 & 0.90 & 0.699 & 0.69 & 0.96 & 0.86 \\
\hline DFA & 67.06 & 65.91 & 68.26 & 66.70 & 0.10 & 0.546 & 0.24 & 0.16 & 0.08 \\
\hline$n-6: n-3$ & 6.31 & 6.56 & 7.98 & 7.31 & 0.09 & 1.341 & 0.41 & 0.02 & 0.53 \\
\hline PUFA:SFA & 0.19 & 0.25 & 0.25 & 0.21 & 0.52 & 0.087 & 0.97 & 0.48 & 0.75 \\
\hline $\mathrm{Al}$ & 0.69 & 0.78 & 0.72 & 0.82 & 0.13 & 0.023 & 0.41 & 0.08 & 0.78 \\
\hline TI & 2.10 & 2.16 & 2.04 & 2.17 & 0.22 & 0.034 & 0.09 & 0.68 & 0.10 \\
\hline
\end{tabular}

1 and 2 see Table 2; CLA - conjugated linoleic acids; SFA - saturated fatty acids; MUFA - monounsaturated fatty acids; PUFA - polyunsaturated fatty acids; DFA - desirable fatty acids = MUFA + PUFA + C18:0; Al atherogenic index $=(C 12: 0+4 \times C 14: 0+C 16: 0) /\left(\sum\right.$ MUFA $+\sum n-6$ $\left.+\sum \mathrm{n}-3\right) ; \mathrm{TI}-$ thrombogenic index $=(\mathrm{C} 14: 0+\mathrm{C} 16: 0+\mathrm{C} 18: 0) /(0.5 \times$ $\sum$ MUFA $\left.+0.5 \times \sum n-6+3 \times \sum n-3+\sum n-6\right) / \sum n-3 ;$ ab - means within a row with different superscripts are significantly different at $P<0.05$

The major PUFA was C18:2n-6 with no differences between groups; the content of $\mathrm{C} 20: 2 \mathrm{n}-6$, however, significantly differ among groups - in BarAco group it was higher than in AcoBar and BarBar ( 0.8 vs 0.45 and 0.46 , respectively), moreover the contrast $\mathrm{C}_{2}$ was significant $(P<0.01)$. The content of $\mathrm{C} 18: 3 n-3$ was the highest in AcoAco and AcoBar groups and the lowest in BarBar group, while
BarAco group did not differ from any other group. For this $\mathrm{FA}$ both $\mathrm{C}_{2}$ and $\mathrm{C}_{3}$ contrasts were significant pointing higher values in animals fed acorn during suckling period and the lowest value in BarBar group in comparison to other groups. The content of CLA was higher in groups consuming acorn during suckling period than in other groups $(P<0.05$ for contrast $\mathrm{C}_{2}$ ).

The total PUFA content ranged between 10 and $13 \%$ of the total FA without a significant difference between the groups. The n-6:n-3 ratio tended to be lower $(P<0.09)$ in AcoAco and AcoBar (average 6.4) groups than in BarAco and BarBar lambs (average 7.7) and contrast $C_{2}$ was significant $(P<0.02)$. The PUFA:SFA ratio averaged 0.22 without a significant difference between dietary treatments. In addition, DFA was not affected by the dietary treatment $(P>0.05)$. Also the atherogenic $(\mathrm{AI})$ and thrombogenic (TI) indexes did not differ between treatments.

\section{Sensorial properties}

The effects of incorporating acorn on the sensory attributes of lamb meat are shown in Table 5. The majority of these attributes varied significantly between groups being higher for acorn groups. In fact, the tenderness and juiciness were higher in AcoAco group in comparison with AcoBar and BarBar, moreover the contrast $\mathrm{C}_{2}$ was significant $(P<0.02$ for both parameters). The acceptance was higher in AcoAco than in BarBar group, while the contrast $\mathrm{C}_{1}$ and contrast $\mathrm{C}_{3}$ were significant $(P<0.03$ and $P<0.04$, respectively) showing higher acceptance for meat obtained from animals fed acorn during finishing and the lowest one for meat from BarBar animals. The flavour was similar in all groups $(P>0.05)$; however the contrast $\mathrm{C}_{3}$ was significant $(P<0.04)$ showing worse meat flavour in group BarBar.

Table 5. Sensory evaluation of meat

\begin{tabular}{|c|c|c|c|c|c|c|c|c|c|}
\hline \multirow[b]{2}{*}{ Indices } & \multicolumn{4}{|c|}{ Groups ${ }^{1}$} & \multicolumn{5}{|c|}{ Statistics $^{2}$} \\
\hline & $\begin{array}{l}\text { Aco- } \\
\text { Aco }\end{array}$ & $\begin{array}{l}\text { Aco- } \\
\text { Bar }\end{array}$ & $\begin{array}{l}\text { Bar- } \\
\text { Aco }\end{array}$ & $\begin{array}{l}\text { Bar- } \\
\text { Bar }\end{array}$ & $\begin{array}{l}P- \\
\text { value }\end{array}$ & SEM & $\mathrm{C}_{1}$ & $\mathrm{C}_{2}$ & $\mathrm{C}_{3}$ \\
\hline Tenderness $^{3}$ & $3.0^{\mathrm{a}}$ & $6.2^{b}$ & $6.5^{a b}$ & $6.2^{b}$ & 0.08 & 0.62 & 0.02 & 0.36 & 0.23 \\
\hline Juiciness ${ }^{4}$ & $6.2^{\mathrm{a}}$ & $5.4^{b}$ & $5.7^{\mathrm{ab}}$ & $5.5^{\mathrm{b}}$ & 0.04 & 0.56 & 0.02 & 0.35 & 0.29 \\
\hline Flavour ${ }^{5}$ & 6.6 & 6.6 & 6.4 & 6.0 & 0.22 & 0.68 & 0.28 & 0.11 & 0.04 \\
\hline Acceptance ${ }^{6}$ & $6.8^{a}$ & $6.3^{\mathrm{ab}}$ & $6.4^{\mathrm{ab}}$ & $5.9^{b}$ & 0.08 & 0.63 & 0.03 & 0.14 & 0.04 \\
\hline
\end{tabular}

1 and 2 see Table $2 ;{ }^{3}$ tenderness: scale $1-10$ where $1=$ extremely tough and $10=$ extremely tender; ${ }^{4}$ juiciness: scale $1-10$ where $1=$ extremely dry and $10=$ extremely juicy; ${ }^{5}$ flavour: scale $1-10$ where $1=$ very poor and $10=$ very good; ${ }^{6}$ overall acceptability: scale $1-10$ where $1=$ not acceptable and $10=$ extremely acceptable; ${ }^{\text {ab }}$ - means within a row with different superscripts are significantly different at $P<0.05$ 


\section{Discussion}

\section{Diet intake and growth performances}

Both concentrates, with and without acorn, have similar energy and nitrogen values. The intake of hay and concentrate was similar among the groups. Therefore, acorn intake had no repercussion on forage and concentrate intake by lambs unfamiliar with acorn (BarAco). Also, it seems to be appetizing for sheep. Previously Al Jassim et al. (1998) showed that acorn was not rejected by lambs.

Growth rates were similar for all groups. This similarity could be due to the similarity in both intake amounts and nutritive values of concentrate with or without acorn; similar results of the use of pomegranate as dietary alternative source were found by Kotsampasi et al. (2014). Moreover, all animals finished the experiment without any signs of health problems, thus confirming the conclusions found by Al Jassim et al. (1998).

\section{Meat physical and chemical analysis}

The effect of dietary treatment on initial $\mathrm{pH}$ $\left(\mathrm{pH}_{\mathrm{hh}}\right)$ showed lower $\mathrm{pH}$ values in animals fed acorn in the suckling period (contrast $\mathrm{C}_{2}$ ). The difference can be explained by the fact that lambs had different reactions to the same stress. The ultimate $\mathrm{pH}\left(\mathrm{pH}_{24 \mathrm{~h}}\right)$ values of all groups were within the normal range of lamb meat as was found by Kuchtík et al. (2012) as well. This result presumes that the glycogen stocks achieved by diets containing both barley and acorn were similar to those of solely barley. There was stated no difference in WCL regardless observed difference in the $\left(\mathrm{pH}_{1}-\mathrm{pH}_{24 \mathrm{~h}}\right)$. It has been shown that the WHC of meat is positively correlated to the rate of decrease in $\mathrm{pH}$ from 1 to $24 \mathrm{~h}$ post mortem more than to its value at $24 \mathrm{~h}$ (Kuchtik et al., 2012). The absence of dietary effect on ultimate $\mathrm{pH}$ and fat content could explain the similarity of fat and muscle colour parameters (Manso et al., 2009). Likewise, all diets resulted in meat which met the norm for acceptable colour - a luminosity index above 40 for all groups, a value considered the threshold of meat acceptability by $95 \%$ of consumers (Khliji et al., 2010). Thus, acorn intake did not alter meat colour or acceptability by consumers. The similarity in meat chemical composition could have resulted from the similarity of the slaughter weight (Atti and Mahouachi, 2009). Moreover, muscle colour depends essentially on the precocity of the breed during the development stage. Since the lambs were in the same age and at the same stage of maturity, no differences in muscle colour were detected (Hajji et al., 2016).

\section{Fatty acid composition}

The values of C16:0, C18:0 and C18:1 FA are consistent with those commonly accepted for the FA composition of lamb meat for both thin-tailed (Manso et al., 2009; Keddam et al., 2010) and fattailed sheep (Atti and Mahouachi, 2009; Yousefi et al., 2012). Both groups fattened with acorn concentrate (AcoAco and BarAco) had a higher proportion of C18:0 than sheep which did not receive it in this phase (AcoBar and BarBar). However, it is worthwhile to note that both acorn and barley concentrates, resulted in an exceptionally high value of C18:0 which engendered a high total SFA proportion $(>50 \%)$. These high rates can be explained by the high bio-hydrogenation process of unsaturated FA into SFA. It is worthwhile to note that the mean value of stearic acid recorded in this study (22-26\%) was higher than those recorded both for heavy lambs (44 kg BW) of the same breed fed conventional concentrate (17.1\%; Atti and Mahouachi, 2009) and for Merino lambs slaughtered at $25 \mathrm{~kg}$ BW (16.5\%; Manso et al., 2009).

The similarity in total MUFA and C18:1n-9c contents for all groups confirmed the lack of effects of an acorn diet on MUFA in lamb meat (Keddam et al., 2010); however, these authors recorded higher contents of MUFA (45\%) and C18:1n-9c (40\%) than those found in our study (32 and 28\% for MUFA and C18:1n-9c, respectively). Despite the similarity in FA composition of olive cake and acorns, particularly their richness in oleic acid, the C18:1 content in the subcutaneous fat of lambs receiving olive cake was higher than that in lambs receiving barley concentrate (47 and 43\%, respectively; Vera et al., 2009).

The PUFA content is comparable to that reported by Keddam et al. (2010) for lambs fed barley or acorn based concentrate. Acorn intake increased the $\mathrm{C} 18: 3 n-3$ content in LD muscle regardless the period of acorn feeding (before or after weaning; although in the suckling period the effect was more pronounced) and CLA concentration in meat of animals fed diet with acorn during suckling period. As both these FA are considered very beneficial for human health and C18:3n-3 is regarded as a precursor of the n-3 PUFA series, more attention should be paid to using acorn in lamb nutrition particularly in the suckling period. The higher C18:3n-3 proportion in meat from the AcoAco and AcoBar groups in comparison to BarBar group can be attributed to the higher intake of this FA; the acorn C18:3n-3 content is higher than that of barley one (1.5 and 0.23 , respectively; Table 1$)$. This result was achieved despite the phenomenon of ruminal 
biohydrogenation of PUFA. In fact, the richness of acorn in phenolic compounds, condensed tannins in particular, could limit this phenomenon as shown by Gravador et al. (2015) where lambs were fed carob pulp partially substituted to barley in concentrate. In the present study, n-6:n-3 ratio, considered as an index of healthiness, tended to be improved by the acorn diet during the suckling period. A similar tendency was shown for lambs fed acorn by Keddam et al. (2010). A low n-6:n-3 ratio decreases the risk of cardiovascular diseases and some types of cancer when it is around 2 (Simopoulos, 2008). Another interesting index is the content of desirable fatty acids (DFA) which could be considered as a good indicator of the relative nutritional values of the meat (Banskalieva et al., 2000). This index includes MUFA, PUFA and C18:0. The stearic acid, although saturated, is neutral and can be converted into oleic acid (C18:1) in the human body. In this study, the sum of DFA was similar between groups. Therefore, the acorn intake, regardless of the period of supplementation, did not alter the DFA value.

Another consequence of the high C18:0 content was a generally low PUFA:SFA ratio recorded with and without acorn; it averaged 0.22 for all dietary treatments. This ratio is widely used as an indicator of the health value of meat for humans. To be beneficial for human nutrition, it should be at least $0.4,0.12$ is considered its upper limit (Simopoulos, 2008). Compared to these recommended values, the lamb meat in this study can be treated as acceptable. Likewise, the PUFA:SFA ratios were close to those recorded in lambs reared under different feeding systems (Komprda et al., 2012; Mekki et al., 2016). However, lower values $(0.13)$ were recorded in the same breed (Atti and Mahouachi, 2009) and other breeds (Kuchtik et al., 2012); values, from 0.07 to 0.26 were reported for sheep meat (Banskalieva et al., 2000).

Both AI and TI, important in terms of human health, were similar for all diets. Their values were comparable to those reported by Kuchtik et al. (2012) for lambs with other genotypes, but higher than that reported by Komprda et al. (2012). The high content of C18:0 could engender this elevated TI, thus confirming the hypothesis made by Komprda et al. (2012) about high percentages of stearic acid $(25 \%)$. However, when meat quality is judged for human nutrition it is important to note that the $\mathrm{n}-6: \mathrm{n}-3$ ratio is a more important parameter than AI or TI (Komprda et al., 2012).

\section{Sensorial properties}

The highest value of meat tenderness and overall acceptance (7 and 6.8, respectively) from AcoAco lambs confirmed the results of Jurado et al. (2007) and Pérez-Palacios (2010) working on the effect of acorn intake on pig fresh meat flavour. The latter author showed that the effect of woody pasture on FA profile and flavour was stronger on a dry-cured product than on fresh meat. In this study, acorn intake in the fattening period resulted in higher sensory scores of both juiciness and tenderness. Moreover the flavour was worse in BarBar group regardless the period of feeding when acorn was added to the diet. Such improvement confirmed the common perception on higher sensitive quality of animal products provided from animals being reared in pasture or in forest.

The AcoAco and BarAco groups had the highest score for the majority of sensory parameters. The intake of acorn, a forest product, in the fattening phases, could generate some aromatic property in lamb meat. The general acceptability of meat was also better for groups consuming acorn but even regardless the period of acorn addition to the diet. The effects of dietary treatments on organoleptic properties were shown by Smeti et al. (2014) comparing concentrate-fed to pasture-fed lambs.

\section{Conclusions}

Acorn intake permitted the same growth rate in lambs and did not alter the chemical and physical properties of their meat (except of $\mathrm{pH}$ measured $1 \mathrm{~h}$ post mortem). Moreover, it improved overall scores for the sensory parameters. As acorn is naturally rich in $\alpha$-linolenic acid (C18:3n-3), it is a good feed additive to increase this fatty acid content in meat making it more nutritionally appealing. Also, in the present study the acorn addition during suckling period increased $\alpha$-linolenic acid concentration in meat of lambs leading to the tendency in lowering $n-6: n-3$ ratio. These results should encourage the use of acorns in sheep nutrition. However, acorns addition during the fattening phase increased also the saturated fatty acid (C18:0) content in meat. Due to this heterogeneity, more research is needed to draw conclusions about using acorn to improve lamb meat quality. In addition, an economic study should be undertaken to examine the economic benefits of substituting barley with acorn (Quercus ilex) in concentrate.

\section{Acknowledgements}

This study was conducted as part of a ResearchDevelopment project. The authors wish to thank the Higher School of Agriculture of Kef (ESAK), Agricultural Research Institute of Tunisia (INRAT) 
and Northwest Silvo-Pastoral Development Office (ODESYPANO) for their collaboration and financial support. The authors gratefully acknowledge the technical assistance of general PAF Laboratory staff in the conduct of this study; they are indebted to Zina Taghouti and Jalel Khlil for their technical help during this work.

\section{References}

Ådnøy T., Haug A., Sørheim O., Thomassen M.S., Varszegi Z., Eik L.O., 2005. Grazing on mountain pastures - does it affect meat quality in lambs? Livest. Prod. Sci. 94, 25-31, https:// doi.org/10.1016/j.livprodsci.2004.11.026

Akcan T., Gökçe M., Asensio R., Estévez M., Morcuende D., 2017. Acorn (Quercus spp.) as a novel source of oleic acid and tocopherols for livestock and humans: discrimination of selected species from Mediterranean forest. J. Food Sci. Technol. 54, 3050-3057, https://doi.org/10.1007/s13197-017-2740-3

Al Jassim R.A.M., Ereifej K.I., Shibli R.A., Abudabos A., 1998. Utilization of concentrate diets containing acorns (Quercus aegilops and Quercus coccifera) and urea by growing Awassi lambs. Small Ruminant Res. 29, 289-293, https://doi.org/10.1016/ S0921-4488(97)00124-7

AMSA (American Meat Science Association), 2015. Research Guidelines for Cookery, Sensory Evaluation, and Instrumental Tenderness Measurements of Meat. $2^{\text {nd }}$ Edition. AMSA. Champaign, IL (USA)

AOAC, 1991. Official Methods of Analysis of the Association of Official Analytical Chemists. $15^{\text {th }}$ Edition. Arlington, VA (USA), pp. 69-88

Atti N., Mahouachi M., 2009. Effects of feeding system and nitrogen source on lamb growth, meat characteristics and fatty acid composition. Meat Sci. 81, 344-348, https://doi.org/10.1016/j. meatsci.2008.08.011

Banskalieva V., Sahlu T., Goetsch A.L., 2000. Fatty acid composition of goat muscles and fat depots: a review. Small Ruminant Res. 37, 255-268, https://doi.org/10.1016/S0921-4488(00)00128-0

Bligh E.G., Dyer W.J., 1959. A rapid method of total lipid extraction and purification. Can. J. Biochem. Physiol. 37, 911-917, https:// doi.org/10.1139/059-099

BS EN ISO 5509:2001. Animal and vegetable fats and oils. Preparation of methyl esters of fatty acids. https://doi. org/10.3403/02020190U

Cantos E., Espín J.C., López-Bote C., de la Hoz L., Ordóñez J.A., Tomás-Barberán F.A., 2003. Phenolic compounds and fatty acids from acorns (Quercus spp.), the main dietary constituent of free-ranged Iberian pigs. J. Agric Food. Chem. 51, 6248-6255, https://doi.org/10.1021/jf030216v

Gravador R.S., Luciano G., Jongberg S., Bognanno M., Scerra M., Anderson M.L., Lund M.N., Priolo A., 2015. Fatty acids and oxidative stability of meat from lambs fed carob-containing diets. Food Chem. 182, 27-34, https://doi.org/10.1016/j.foodchem.2015.02.094

Hajji H., Joy M., Ripoll G., Smeti S., Mekki I., Molino Gahete F., Mahouachi M., Atti N., 2016. Meat physicochemical properties, fatty acid profile, lipid oxidation and sensory characteristics from three North African lamb breeds, as influenced by concentrate or pasture finishing diets. J. Food Compos. Anal. 48, 102-110, https://doi.org/10.1016/j.jfca.2016.02.011
Hassoun P., Bocquier F., 2010. Sheep nutrition (in French). In: J. Agabriel (Editor). Cattle, Sheep and Goat Nutrition. Animal Requirements - Value of Feed. INRA Tables 2007. Revised Edition (in French). Éditions Quæ (INRA). Versailles Cedex (France), pp. 123-137

House of Lords Select Committee on the European Communities, 1999. Sixteenth Report. Organic Farming and the European Union. https://publications.parliament.uk/pa/ld199899/ldselect/ Ideucom/93/9301.htm

Jurado Á., García C., Timón M.L., Carrapiso A.I., 2007. Effect of ripening time and rearing system on amino acid-related flavour compounds of Iberian ham. Meat Sci. 75, 585-594, https:// doi.org/10.1016/j.meatsci.2006.09.006

Keddam R., Bouderoua K., El-Affifi M., Selselet-Attou G., 2010. Growth performances, carcasses parameters and meat fatty acid composition of lamb fed green oak acorns (Quercus ilex) based diet. Afr. J. Biotechnol. 9, 4631-4637

Khliji S., van de Ven R., Lamb T.A., Lanza M., Hopkins D.L., 2010. Relationship between consumer ranking of lamb colour and objective measures of colour. Meat Sci. 85, 224-229, https:// doi.org/10.1016/j.meatsci.2010.01.002

Komprda T., Kuchtík J., Jarošová A., Dračková E., Zemánek L., Filipčík B., 2012. Meat quality characteristics of lambs of three organically raised breeds. Meat Sci. 91, 499-505, https://doi. org/10.1016/j.meatsci.2012.03.004

Kotsampasi B., Christodoulou V., Zotos A., Liakopoulou-Kyriakides M., Goulas P., Petrotos K., Natas P., Bampidis V.A., 2014. Effects of dietary pomegranate byproduct silage supplementation on performance, carcass characteristics and meat quality of growing lambs. Anim. Feed Sci. Technol. 197, 92-102, https:// doi.org/10.1016/j.anifeedsci.2014.09.003

Kuchtík J., Zapletal D., Šustová K., 2012. Chemical and physical characteristics of lamb meat related to crossbreeding of Romanov ewes with Suffolk and Charollais sires. Meat Sci. 90, 426430, https://doi.org/10.1016/j.meatsci.2011.08.012

Manso T., Bodas R., Castro T., Jimeno V., Mantecon A.R., 2009. Animal performance and fatty acid composition of lambs fed with different vegetable oils. Meat Sci. 83, 511-516, https://doi. org/10.1016/j.meatsci.2009.06.035

Mekki I., Camin F., Perini M., Smeti S., Hajji H., Mahouachi M., Piasentier E., Atti N., 2016. Differentiating the geographical origin of Tunisian indigenous lamb using stable isotope ratio and fatty acid content. J. Food Compos. Anal. 53, 40-48, https://doi. org/10.1016/j.jfca.2016.09.002

Pérez-Palacios T., Antequera T., Durán M.L., Caro A., Rodríguez P.G., Ruiz J., 2010. MRI-based analysis, lipid composition and sensory traits for studying lberian dry-cured hams from pigs fed with different diets. Food Res. Int. 43, 248-254, https://doi. org/10.1016/j.foodres.2009.09.020

Ponnampalam E.N., Burnett V.F., Norng S., Hopkins D.L., Plozza T., Jacobs J.L., 2016. Muscle antioxidant (vitamin E) and major fatty acid groups, lipid oxidation and retail colour of meat from lambs fed a roughage based diet with flaxseed or algae. Meat. Sci. 111, 154-160, https://doi.org/10.1016/j. meatsci.2015.09.007

Simopoulos A.P., 2008. The importance of the omega-6/omega-3 fatty acid ratio in cardiovascular disease and other chronic diseases. Exp. Biol. Med. 233, 674-688, https://doi. org/10.3181/0711-MR-311

Smeti S., Mahouachi M., Atti N., 2014. Effects of finishing lambs in rich aromatic plant pasture or in feedlot on lamb growth and meat quality. J. Appl. Anim. Res. 42, 297-303, https://doi.org/10.10 80/09712119.2013.845102

Ulbricht T.L.V., Southgate D.A.T., 1991. Coronary heart disease: seven dietary factors. Lancet 338, 985-992, https://doi. org/10.1016/0140-6736(91)91846-M 
Vera R., Aguilar C., Lira R. et al., 2009. Feeding dry olive cake modifies subcutaneous fat composition in lambs, noting cake resistance to degradation and peroxidation. Chilean J. Agric. Res. 69, 548-559, https://doi.org/10.4067/S071858392009000400010
Yousefi A.R., Kohram H., Shahneh A.Z., Nik-khah A., Campbell A.W., 2012. Comparison of the meat quality and fatty acid composition of traditional fat-tailed (Chall) and tailed (Zel) Iranian sheep breeds. Meat Sci. 92, 417-442, https://doi. org/10.1016/j.meatsci.2012.05.004 